\title{
MÚLTIPLOS E ÚNICOS
}

Paula Soares é técnica em assuntos educacionais e mestranda em Estudos de Linguagem na UFF.

E-mail:paulagfs@hotmail.com

O corpo da mulata

Samba e balança

O sorriso é estática

Uma tática

De confiança e insegurança

O corpo da modelo

A riqueza da magreza

Do desfile é cabide

E transgride

$\mathrm{Na}$ cegueira, a incerteza

O corpo da mãe

Tão sagrado quanto cansado

Da família é fortaleza

Uma realeza

Nos quadros do passado

O corpo da mulher

Múltiplo e Único

Já cantado e admirado

Tom Jobim, por ele, sofreu

Chico Buarque, através dele, entendeu

E Maysa, nele, se perdeu

Nem todos ultrapassam o físico

Mas alguns tocam música e alma

Hoje, o corpo atado em liberdade

Com calma, nas vitrines é exposto

Em cada gesto oposto

Um conceito imposto pela autoridade

O corpo que não existe

Ainda sim, resiste

E nunca irá amadurecer

O corpo da tv

Além do que você vê

E não deixa transparecer

Na procura pela perfeição ideal

Vem a loucura da lamentação do consumível 
Numa constante contradição atemporal:

Vale a beleza interior, se for visível

\section{Corpo}

Por trás da lente, é material

Por trás da mente, é imaginário

Ou ao contrário

Enfrente a dúvida: o que é real? 